\title{
Upregulation of Peptide Transporters PEPT1 and PEPT2 by Janus Kinase JAK2
}

\author{
Zohreh Hosseinzadeha,b Luo Dong ${ }^{\mathrm{a}, \mathrm{b}}$ Shefalee K. Bhavsar ${ }^{\mathrm{a}} \quad$ Jamshed Warsi $^{\mathrm{a}}$ \\ Ahmad Almilajia Florian Lang ${ }^{a}$
}

${ }^{a}$ Department of Physiology 1, University of Tübingen, Tübingen; ${ }^{b}$ contributed equally and thus share first authorship

\section{Key Words}

Peptide transport • Nutrient transport • JAK2 inhibitor AG490 • Energy depletion • Intestine

\begin{abstract}
Background/Aims: Janus-activated kinase-2 JAK2 participates in the signaling of several hormones including growth hormone, fosters tumor growth and modifies the activity of several $\mathrm{Na}^{+}$coupled nutrient transporters. Peptide uptake into intestinal and tumor cells is accomplished by electrogenic peptide transporters PEPT1 and PEPT2. The present study thus explored whether JAK2 contributes to the regulation of PEPT1 and PEPT2 activity. Methods: CRNA encoding either PEPT1 or PEPT2 was injected into Xenopus oocytes with or without additional injection of CRNA encoding wild type JAK2, constitutively active V617FJAK2 or inactive K882EJAK2. The current created by the dipeptide glycine-glycine $\left(\mathrm{I}_{\text {gly-gly }}\right)$ was determined by dual electrode voltage clamp and taken as measure for electrogenic peptide transport. Results: No appreciable $I_{\text {gly-gly }}$ was observed in water injected oocytes. In PEPT1 or PEPT2 expressing oocytes $I_{\text {gly-gly }}$ was significantly increased by additional coexpression of JAK2. As shown in PEPT1 expressing oocytes, $\mathrm{I}_{\text {gly-gly }}$ was increased by coexpression of ${ }^{\mathrm{V} 617 F} J A K 2$, but not of ${ }^{\mathrm{K} 882 \mathrm{E} J A K 2}$. JAK2 enhanced maximal $\mathrm{I}_{\text {gly- }}$ gly without significantly modifying the concentration required for halfmaximal $I_{\text {gly-gly }}\left(K_{M}\right)$. Following disruption of carrier insertion with brefeldin A $(5 \mu \mathrm{M}) I_{\text {gly-gly }}$ declined similarly fast in Xenopus oocytes expressing PEPT1 with JAK2 and in Xenopus oocytes expressing PEPT1 alone. In oocytes expressing both, PEPT1 and V617FJAK2, I gly-gly was gradually decreased by JAK2 inhibitor AG490 $(40 \mu \mathrm{M})$. According to Ussing chamber experiments pharmacological JAK2 inhibition similarly decreased $\mathrm{I}_{\text {gly-gly }}$ in mouse intestine. Conclusion: Regulation of the peptide transporters PEPT1 and PEPT2 does involve the Janus-activated kinase-2 JAK2.
\end{abstract}




\section{Introduction}

The janus-activated kinase-2 JAK2 is involved in the signaling of a variety of hormones and cytokines [1-3], such as leptin [4], growth hormone [5, 6], erythropoietin [2], thrombopoietin [2] and granulocyte colony-stimulating factor [2]. Moreover, JAK2 is activated by oxidative stress [7], ischemia [7] and hypertonicity [8, 9]. Excessive JAK2 activity may lead to development of malignancy and the gain of function mutation ${ }^{\mathrm{V} 617 \mathrm{~F}} \mathrm{JAK} 2$ presumably predisposes to the development of myeloproliferative disease [10-13]. Conversely, JAK2 inhibitors are considered for the treatment of myeloproliferative disorders [14-19].

JAK2 has most recently been shown to be involved in the regulation of several transporters including the betaine/GABA transporter BGT1 [20], the creatine transporter CreaT [21], the glucose transporter SGLT1 [22] and several amino acid transporters [23, 24]. Transporters contributing to intestinal nutrient uptake and expressed in tumor cells include the peptide transporters 1 (PEPT1) and 2 (PEPT2), carriers mediating the cellular uptake of di- and tripeptides [25-27]. The carriers further mediate the cellular uptake of peptide-like drugs $[25,26]$. Thus, regulation of PEPT1/PEPT2 activity may impact on the sensitivity of tumor cells to those drugs.

Previous experiments revealed that intestinal peptide transport is up-regulated by the PI3kinase pathway [28] and by glucocortioids [29], both effects at least partially mediated by the serum \& glucocorticoid inducible kinase SGK1 [30]. PEPT1 is further regulated by AMP activated kinase [31]. Peptide transport is stimulated by leptin [32] and growth hormone [33]. The signaling linking the leptin receptor to peptide transport is not known but could, at least in theory, involve JAK2.

The present study thus explored whether JAK2 influences the peptide transporters PEPT1 and/or PEPT2. To this end, cRNA encoding the peptide transporters was injected into Xenopus oocytes with or without cRNA encoding wild type JAK2, constitutively active ${ }^{\mathrm{V} 617 \mathrm{~F} J A K 2}$ or inactive ${ }^{\mathrm{K} 882 \mathrm{E} J A K 2}$ and peptide transport estimated from peptide induced current. To explore whether JAK2 sensitivity of electrogenic peptide transport may be relevant in vivo, additional Ussing experiments were performed elucidating the effect of pharmacological JAK2 inhibition on peptide induced current in intestine.

\section{Materials and Methods}

\section{Constructs}

Constructs were used encoding PEPT1 and PEPT2 [30] as well as wild-type human JAK2, inactive ${ }^{\mathrm{K} 82 \mathrm{E}} \mathrm{JAK} 2$ mutant [34] and the ${ }^{\mathrm{V} 617 \mathrm{~F}} \mathrm{JAK} 2$ mutant $[13,22,24]$. The constructs were used for generation of cRNA as described previously [35, 36].

\section{Voltage clamp in Xenopus oocytes}

Xenopus oocytes were prepared as previously described [37, 38]. Where not indicated otherwise, 10 ng PEPT1 and PEPT2 cRNA were injected on the first day and $10 \mathrm{ng}$ of wild type JAK2 cRNA injected on the second day or same day after preparation of the oocytes [39]. The oocytes were maintained at $17^{\circ} \mathrm{C}$ in ND96 solution containing (in $\mathrm{mM}$ ): $96 \mathrm{NaCl}, 4 \mathrm{KCl}, 1.8 \mathrm{MgC12}, 0.1 \mathrm{CaC} 12,5 \mathrm{HEPES}, \mathrm{pH} 7.4$, gentamycin (50 mg/l), tetracycline (50 mg/l), ciprofloxacin (1.6 mg/l), refobacin (100 mg/l), theophiline (90 mg/l). Where indicated, the JAK2 inhibitor AG490 $(40 \mu \mathrm{M})$ or brefeldin A $(5 \mu \mathrm{M})$ were added to the respective solutions. The voltage clamp experiments were performed at room temperature 3 days after injection [40, 41]. Two-electrode voltage-clamp recordings were performed at a holding potential of $-60 \mathrm{mV}$. The data were filtered at $10 \mathrm{~Hz}$ and recorded with a Digidata A/D-D/A converter and Clampex 9.2 software for data acquisition and analysis (Axon Instruments) [24]. The control superfusate (ND96) contained $96 \mathrm{mM} \mathrm{NaCl}$, $2 \mathrm{mM} \mathrm{KCl}, 1.8 \mathrm{mM} \mathrm{CaCl}_{2}, 1 \mathrm{mM} \mathrm{MgCl}_{2}$ and $5 \mathrm{mM}$ HEPES, pH 7.4. Glycine-glycine was added to the solutions at a concentration of $1 \mathrm{mM}$, unless otherwise stated. The flow rate of the superfusion was approx. $20 \mathrm{ml} / \mathrm{min}$, and a complete exchange of the bath solution was reached within about $10 \mathrm{~s}$. 
Fig. 1. Coexpression of JAK2 increases electrogenic peptide transport in PEPT1-expressing Xenopus oocytes. A: Representative original tracings showing glycine-glycine $(1 \mathrm{mM})$ - induced current $\left(\mathrm{I}_{\text {gly-gly }}\right)$ in Xenopus oocytes injected with water (a), expressing wild type JAK2 alone (b), or expressing PEPT1 without (c) or with (d) additional coexpression of wild type JAK2. B: Arithmetic means \pm SEM $(n=15)$ of glycine-glycine $(1 \mathrm{mM})$ - induced current $\left(\mathrm{I}_{\text {gly-gly }}\right)$ in Xenopus oocytes injected with water $\left(\mathrm{H}_{2} \mathrm{O}\right.$, light grey bar), expressing JAK2 alone (JAK2, dark grey bar), or expressing PEPT1 without (PEPT1, white bar) or with (PEPT1+JAK2, black bar) additional coexpression of wild type JAK2. The respective values \pm standard deviation are $(1.8 \pm 1.1,2.2 \pm 1.3,41 \pm 8,52 \pm$ 10 , respectively). ${ }^{* * *}$ indicates statistically significant $(p<0.001)$ difference from the absence of PEPT1. \# indicates statistically significant $(p<0.05)$ difference from the absence of JAK2. C: Arithmetic means \pm SEM $(\mathrm{n}=15)$ of glycine-glycine-induced current $\left(\mathrm{I}_{\text {gly-gly }}\right)$ as a function of glycine-glycine concentration in Xenopus oocytes expressing PEPT1 without (open circles, dashed line), or with (closed circles, solid line) additional coexpression of wild type JAK2.



\section{Ussing chamber experiments}

All animal experiments were conducted according to the German law for the welfare of animals and were approved by local authorities. Experiments have been performed using intestinal segments from mice, fed a control diet (1314, Altromin, Heidenau, Germany) and having free access to tap drinking water.

For analysis of electrogenic intestinal peptide transport, jejunal segments were mounted into a custom made mini-Ussing chamber with an opening of $0.00769 \mathrm{~cm}^{2}$. Under control conditions, the serosal and luminal perfusate contained (in mM): $115 \mathrm{NaCl}, 2 \mathrm{KCl}, 1 \mathrm{MgCl}_{2}, 1.25 \mathrm{CaCl}_{2}, 0.4 \mathrm{KH}_{2} \mathrm{PO}_{4}, 1.6 \mathrm{~K}_{2} \mathrm{HPO}_{4}, 5 \mathrm{Na}$ pyruvate, $25 \mathrm{NaHCO}_{3}(\mathrm{pH} 7.4, \mathrm{NaOH})$. Where indicated, the dipeptide glycine-glycine $(5 \mathrm{mM})$ was added to the luminal perfusate at the expense of mannitol $(10 \mathrm{mM}$ ) (all substances were from Sigma, Schnelldorf, Germany, or from Roth, Karlsruhe, Germany). In all Ussing chamber experiments the transepithelial potential difference $(\mathrm{Vt})$ was determined continuously and the transepithelial resistance (Rt) was estimated from the voltage deflections $(\Delta \mathrm{Vt})$ elicited by imposing test currents $\left(\mathrm{I}_{\mathrm{t}}\right)$. The resulting Rt was calculated according to Ohm's law [29].

\section{Statistical analysis}

Data are provided as means \pm SEM, $n$ represents the number of oocytes or intestinal segments investigated. All voltage clamp experiments were repeated with at least 2-3 batches of oocytes; in all repetitions qualitatively similar data were obtained. Data were tested for significance using ANOVA or t-test, as appropriate. Results with $\mathrm{p}<0.05$ were considered statistically significant.

\section{Results}

The present study explored, whether Janus kinase-2 (JAK2) participates in the regulation of the peptide transporters PEPT1 and PEPT2. To this end, cRNA encoding PEPT1 or PEPT2 were injected into Xenopus oocytes with or without additional injection of cRNA encoding JAK2. As PEPT1 and PEPT2 are electrogenic transporters, the peptide transport was 


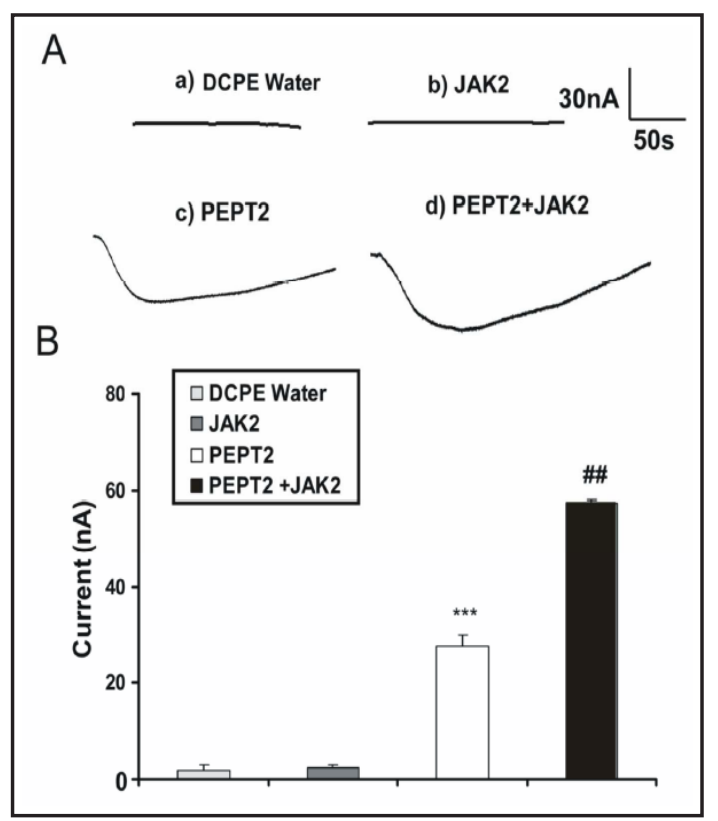

Fig. 2. Coexpression of JAK2 increases electrogenic peptide transport in PEPT2-expressing Xenopus oocytes. A: Representative original tracings showing glycine-glycine $(1 \mathrm{mM})$ - induced current $\left(\mathrm{I}_{\text {gly-gly }}\right)$ in Xenopus oocytes injected with water (a), expressing wild type JAK2 alone (b), or expressing PEPT2 without (c) or with (d) additional coexpression of wild type JAK2. B: Arithmetic means \pm SEM $(n=14)$ of glycine-glycine $(1 \mathrm{mM})$ - induced current $\left(\mathrm{I}_{\text {gly-gly }}\right)$ in Xenopus oocytes injected with water $\left(\mathrm{H}_{2} \mathrm{O}\right.$, light grey bar), expressing JAK2 alone (JAK2, dark grey bar) or expressing PEPT2 without (PEPT2, white bar) or with (PEPT2+JAK2, black bar) additional coexpression of wild type JAK2. *** indicates statistically significant $(\mathrm{p}<0.001)$ difference from the absence of PEPT2. \#\#\# indicates statistically significant $(p<0.001)$ difference from the absence of JAK2.

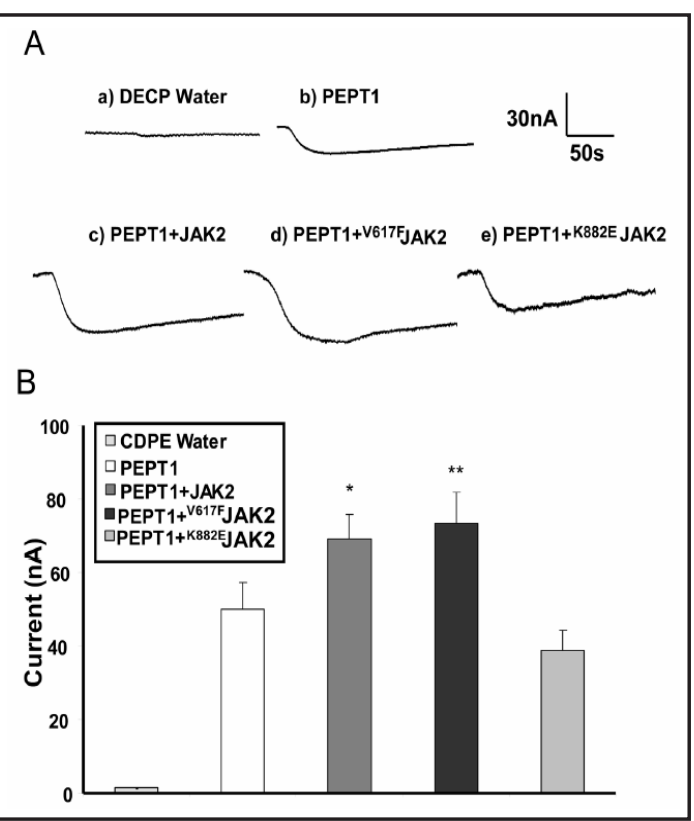

Fig. 3. The effect of JAK2 is mimicked by ${ }^{\mathrm{V} 617 \mathrm{~F} J A K 2}$ but not by the inactive mutant ${ }^{\mathrm{K} 82 \mathrm{E}} \mathrm{JAK} 2$. A: Representative original tracings showing glycine-glycine (1 $\mathrm{mM})$ - induced current $\left(\mathrm{I}_{\text {gly-gly }}\right)$ in Xenopus oocytes injected with water (a), expressing PEPT1 alone (b), or expressing PEPT1 with JAK2 (c), with constitutively active ${ }^{\mathrm{V} 617 \mathrm{~F}} \mathrm{JAK} 2(\mathrm{~d})$, or with the inactive mutant

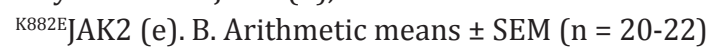
of glycine-glycine $(1 \mathrm{mM})$ - induced current $\left(\mathrm{I}_{\text {gly-gly }}\right)$ in Xenopus oocytes injected with water $\left(\mathrm{H}_{2} \mathrm{O}\right.$, light grey bar), expressing PEPT1 without (PEPT1, white bar) or with wild type JAK2 (PEPT + JAK2, dark grey bar), with constitutively active ${ }^{\mathrm{V} 617 \mathrm{~F}} \mathrm{JAK} 2$ (PEPT1+ ${ }^{\mathrm{V} 617 \mathrm{~F}} \mathrm{JAK} 2$, black bar) or with the inactive mutant ${ }^{\mathrm{K} 82 \mathrm{E}} \mathrm{JAK} 2$ (PEPT1+ ${ }^{\mathrm{K} 822 \mathrm{E}} \mathrm{JAK} 2$, light grey bar) $*$, ** indicates statistically significant $(\mathrm{p}<0.05, \mathrm{p}<0.01)$ difference to expression of PEPT1 alone.

estimated from the current generated upon addition of the dipeptide glycine-glycine $\left(\mathrm{I}_{\text {gly-gly }}\right)$. No appreciable current was observed following exposure of non-injected or water-injected Xenopus oocytes to $1 \mathrm{mM}$ glycine-glycine. Thus, Xenopus oocytes do not express appreciable endogenous electrogenic glycine-glycine transport (Fig. 1A,B). Moreover, no appreciable $\mathrm{I}_{\text {gly-gly }}$ was observed in Xenopus oocytes expressing wild type JAK2 alone (Fig. 1A,B). $\mathrm{I}_{\text {gly-gly }}$ was, however, observed in Xenopus oocytes injected with cRNA encoding PEPT1. The additional injection of cRNA encoding wild type JAK2 was followed by a significant increase of $\mathrm{I}_{\text {gly-gly }}$ in PEPT1 expressing Xenopus oocytes (Fig. 1A,B).

Kinetic analysis was employed for the determination of maximal transport rate and affinity of the carrier. As illustrated in Fig. 1C, in PEPT1-expressing Xenopus oocytes $\mathrm{I}_{\text {gly-gly }}$ increased following increase of substrate concentration. The currents allowed calculating a maximal current, which was significantly higher in Xenopus oocytes expressing PEPT1 together with JAK2 $(83.7 \pm 4.5 \mathrm{nA}, \mathrm{n}=15)$, than in Xenopus oocytes expressing PEPT1 
Fig. 4. Effects of brefeldin $\mathrm{A}$ on electrogenic peptide transport in Xenopus oocytes expressing PEPT1 with or without JAK2. A. Arithmetic means \pm SEM $(n=18)$ of glycine-glycine $(1 \mathrm{mM})$ - induced current $\left(\mathrm{I}_{\text {gly-gly }}\right)$ in Xenopus oocytes injected PEPT1 alone (white bars) or expressing PEPT1 together with ${ }^{\mathrm{V} 617 \mathrm{~F} J A K 2}$ and subsequently incubated with or without $5 \mu \mathrm{M}$ brefeldin A (black bars). ** indicates statistically significant $(\mathrm{p}<0.05, \mathrm{p}<0.01)$ difference from the absence of ${ }^{\mathrm{V} 617 \mathrm{~F} J A K 2}$; \#, \#\# indicates statistically significant $(p<0.05, p<0.01)$ difference from the absence of brefeldin $A$.

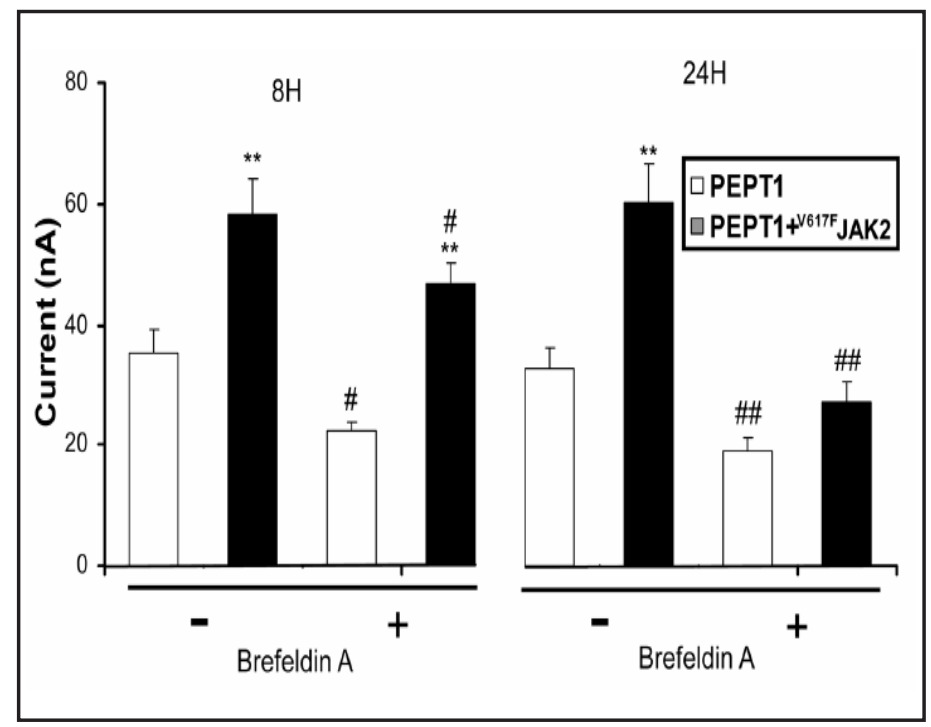

Fig. 5. The effect of ${ }^{\mathrm{V} 617 \mathrm{~F}} \mathrm{JAK} 2$ is reversed by the JAK2 inhibitor AG490. A. Representative original tracings showing glycine-glycine (1 mM) - induced current $\left(\mathrm{I}_{\text {gly-gly }}\right)$ in Xenopus oocytes injected with water (a), expressing PEPT1 (b),


with a 3 hours (d) or 8 hours (e) or 24 hours (f) pretreatment with JAK2 inhibitor AG490 $(40 \mu \mathrm{M})$. B. Arithmetic means \pm SEM $(\mathrm{n}=20)$ of glycine-glycine (1 mM) - induced current $\left(\mathrm{I}_{\text {gly-gly }}\right)$ in Xenopus oocytes expressing PEPT1 without (PEPT1, white bar) or with constitutive active ${ }^{\mathrm{V} 617 \mathrm{~F}} \mathrm{JAK} 2$ (PEPT1+ ${ }^{\mathrm{V} 617 \mathrm{~F}}$ JAK2, black bars) or following pretreatment with the JAK2 inhibitor AG490 (40 $\mu \mathrm{M}$, grey bars) for the indicated time periods. \#\# indicates statistically significant $(\mathrm{p}<0.01)$ difference from the absence of JAK2 inhibitor AG490. *** indicates statistically significant $(\mathrm{p}<0.05, \mathrm{p}<0.01)$ difference from PEPT1 alone (absence of JAK2).

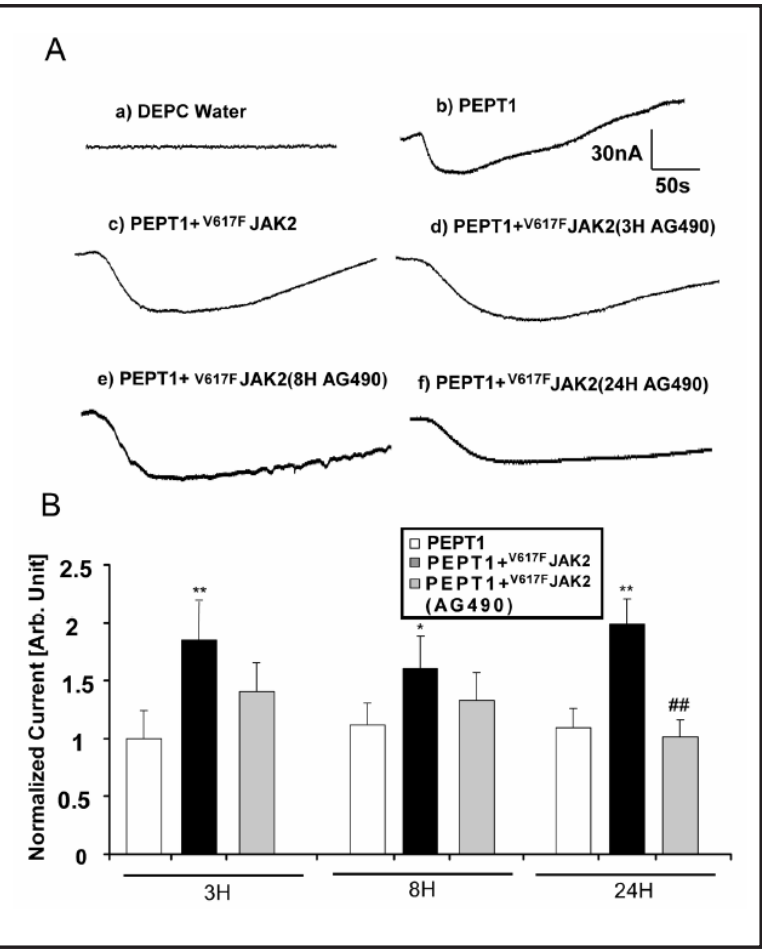

without JAK2 $(65.2 \pm 3.4 \mathrm{nA}, \mathrm{n}=15)$. Accordingly, JAK2 enhanced the maximal transport rate. The glycine-glycine concentration required for halfmaximal current $\left(\mathrm{K}_{\mathrm{M}}\right)$ approached $364 \pm$ $93 \mu \mathrm{M}(\mathrm{n}=15)$ in Xenopus oocytes expressing PEPT1 alone, and $486 \pm 181 \mu \mathrm{M}(\mathrm{n}=15)$ in Xenopus oocytes expressing PEPT1 together JAK2, values not significantly different.

Similar to its effect on PEPT1, JAK2 up-regulated the peptide transporter isoform PEPT2. Similar to what was observed following expression of PEPT1, injection of cRNA encoding PEPT2 resulted in the appearance of glyine-glycine-induced currents. $I_{\text {gly-gly }}$ was higher in Xenopus oocytes injected with cRNA encoding PEPT2 together with JAK2 than in Xenopus oocytes injected with cRNA encoding PEPT2 alone (Fig. 2A,B).

The effect of wild type JAK2 on $\mathrm{I}_{\text {gly-gly }}$ was mimicked by the gain of function mutant ${ }^{\mathrm{V} 617 \mathrm{~F}} \mathrm{JAK} 2$, but not by the inactive mutant ${ }^{\mathrm{K} 82 \mathrm{E}} \mathrm{JAK} 2$ (Fig. 3A,B). Accordingly, $\mathrm{I}_{\text {gly-gly }}$ was significantly higher in Xenopus oocytes expressing PEPT1 together with ${ }^{\mathrm{V} 617 \mathrm{~F}} \mathrm{JAK} 2$ than in 
Fig. 6. Effect JAK2 inhibitor AG490 and JAK2 inhibitor III on glycine-glycineinduced current in intestine. A: Original tracings from typical experiments illustrating the effect of $5 \mathrm{mM}$ glycineglycine on the transepithelial potential difference of intestinal segments without (a) or with (b, c) pretreatment with (b) JAK2 inhibitor III $(20 \mu \mathrm{M})$ or (c) JAK2 inhibitor AG490 $(40 \mu \mathrm{M})$. B: Arithmetic means \pm SEM $(n=6)$ of glycine-glycine (5 $\mathrm{mM}$ ) induced current $\left(\mathrm{I}_{\text {gly-gly }}\right)$ in jejunum in abesence (control, white bar) or presence of JAK2 inhibitor III (grey bar) or JAK2 inhibitor AG490 (black bar). * indicates statistically significant $(\mathrm{p}<0.05)$ difference from absence of inhibitor.

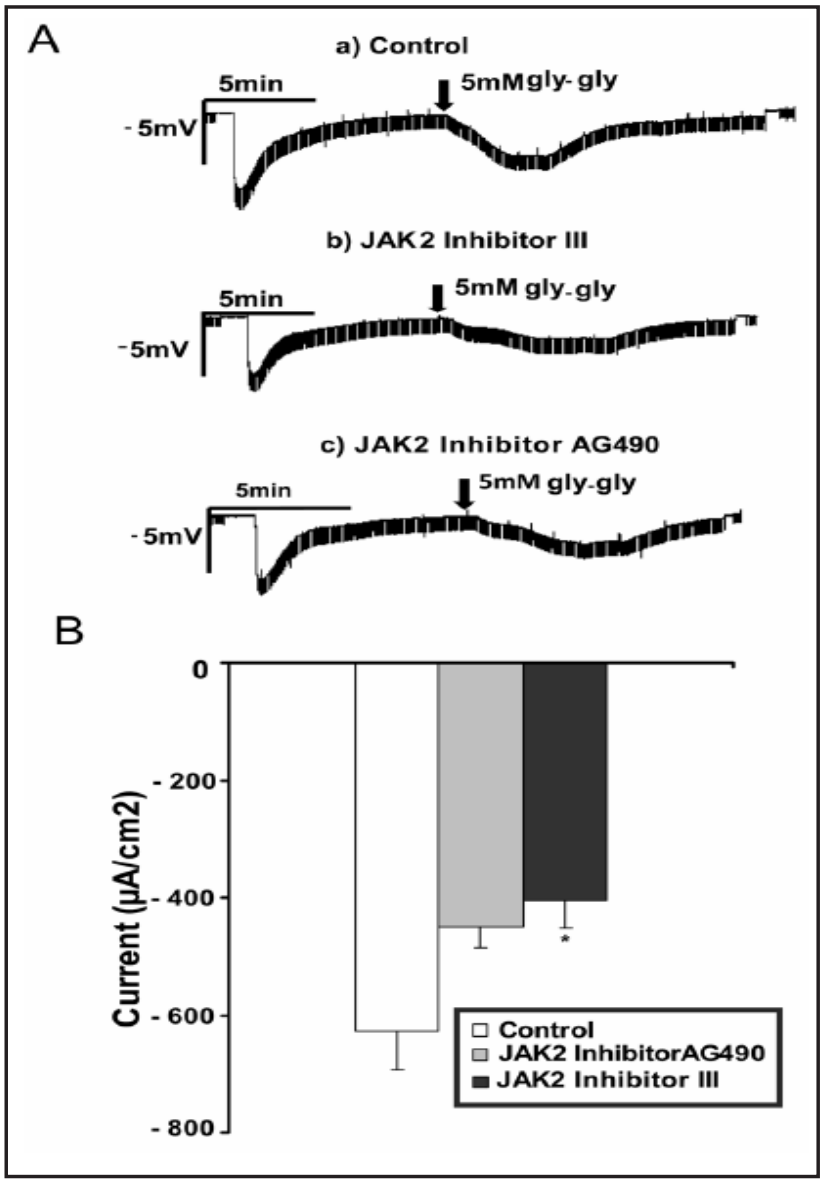

Xenopus oocytes expressing PEPT1 alone. In contrast, $\mathrm{I}_{\text {gly-gly }}$ was similar in Xenopus oocytes expressing PEPT1 together with ${ }^{\mathrm{K} 82 \mathrm{E}} \mathrm{JAK} 2$ and in Xenopus oocytes expressing PEPT1 alone.

At least in theory, the increase of $\mathrm{I}_{\text {gly-gly }}$ in PEPT1 expressing Xenopus oocytes by coexpression of ${ }^{\mathrm{V} 617 \mathrm{~F}} \mathrm{JAK} 2$ could have been due to accelerated clearance of carrier protein from the cell membrane. In order to estimate the stability of $I_{\text {gly-gly, }}$ the PEPT1-expressing Xenopus oocytes were treated with $5 \mu \mathrm{M}$ brefeldin A, a substance blocking the insertion of new carrier protein into the cell membrane. As shown in Fig. 4A, in the presence of brefeldin A $\mathrm{I}_{\mathrm{gly}-\mathrm{gly}}$ declined similarly fast in Xenopus oocytes expressing PEPT1 together with ${ }^{\mathrm{V} 617 \mathrm{~F}} \mathrm{JAK} 2$ and in Xenopus oocytes expressing PEPT1 alone. The observation suggests that ${ }^{\mathrm{V} 617 \mathrm{~F} J A K 2}$ increases $I_{\text {gly-gly }}$ by a mechanism other than accelerating carrier clearance from the cell membrane.

As illustrated in Fig. 5, $\mathrm{I}_{\text {gly-gly }}$ in Xenopus oocytes expressing both, PEPT1 and ${ }^{\mathrm{V} 617 \mathrm{~F} J A K 2}$ was decreased by treatment with the JAK2 inhibitor AG490 $(40 \mu \mathrm{M})$. The effect of the inhibitor on $I_{\text {gly-gly }}$ reached statistical significance within 24 hours of preincubation with AG490.

In order to test, whether the observed regulation of PEPT1 by JAK2 is relevant for peptide transport in vivo, peptide induced current was determined in Ussing chamber experiments of mouse intestinal segments. As illustrated in Fig. 6, addition of glycine-glycine (5 mM) to the luminal perfusate generated a transepithelial current $\left(\mathrm{I}_{\text {gly-gly }}\right)$ which was gradually decreased by treatment with the JAK2 inhibitor AG490 $(40 \mu \mathrm{M})$. The effect of the inhibitor on $\mathrm{I}_{\text {gly-gly }}$ reached statistical significance within 30 min of preincubation with AG490.

\section{Discussion}

The present study identifies a completely novel regulator of the peptide transporters PEPT1 and PEPT2. Coexpression of the Janus Kinase 2 (JAK2) significantly increased the 
electrogenic transport of the dipeptide glycine-glycine in Xenopus oocytes expressing either PEPT1 or PEPT2. The effect of wild type JAK2 was mimicked by the gain of function mutant

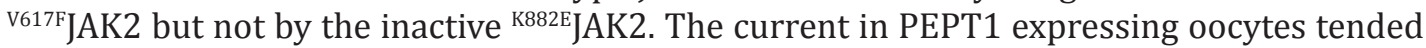
to be lower following coexpression of ${ }^{\mathrm{K} 882 \mathrm{E} J A K 2}$, a difference, however, not reaching statistical significance. An inhibitory effect may have pointed to a transdominant inhibitory action of the inactive kinase.

JAK2 coexpression was effective by increasing the maximal transport rate, an observation compatible with an increase of carrier protein within the cell membrane. In theory, the carrier protein abundance could be modified by alterations of protein insertion into or of protein retrieval from the cell membrane. As the decline of current following brefeldin $\mathrm{A}$ treatment was similar in oocytes coexpressing PEPT1 with JAK2 and oocytes expressing PEPT1 alone, JAK2 was apparently not effective by delaying protein retrieval from the cell membrane. Possibly, JAK2 increases PEPT1 activity by inserting carrier protein into the cell membrane.

The effect of JAK2 was reversed by JAK2 inhibitor AG490. Pharmacological JAK2 inhibition further decreased the peptide induced current in segments of mouse small intestine, an observation pointing to the in vivo significance of JAK2 sensitive regulation of peptide transporters. As selectivity of pharmacological inhibitors may be limited, it remains, however, uncertain whether JAK2 indeed participates in the regulation of intestinal peptide transport. The exposure time required for significant inhibition of peptide transport by AG490 was considerably longer in JAK2 and PEPT1 expressing oocytes than in intestinal segments. It should be kept in mind that the inhibitory effect on cytosolic kinases requires the uptake of the inhibitor across the cell membrane, which may be particularly slow in oocytes.

PEPT1 accomplishes the uptake of luminal di- and tripeptides across the apical enterocyte cell membrane [42, 43] and bile duct epithelium [42]. PEPT2 is expressed mainly by glial cells and by epithelial cells in the kidney, choroid plexus, lung and mammary gland $[42,44]$. Peptide transporters are further expressed in tumor cells $[25,42,45,46]$. JAK2 sensitive peptide transport may be relevant for intestinal nutrient uptake [26, 47], as PEPT1 absorbs the majority of dietary nitrogen [48]. Moreover, PEPT1 has been implicated in inflammatory bowel disease [27]. In healthy individuals the carrier is mainly expressed in small intestine but not in colon. In inflammatory bowel disease, colonic tissue expresses high levels of PEPT1, which participates in peptide trafficking and thus peptide interactions with innate immune receptors. Peptide transporters are further important carriers involved in drug transport, such as beta-lactam antibiotics, angiotensin-converting enzyme inhibitors, antiviral drugs and anti-cancer agents [26, 44, 47, 49-51]. JAK2 sensitive nutrient and drug uptake by peptide transporters may be relevant for the growth, survival and drug sensitivity of tumor cells $[25,31,52,53]$. Peptide transporters have thus been considered as potential targets for tumor therapy [54].

According to previous observations JAK2 stimulates cellular glucose uptake by affecting both, facilitative glucose carriers $[55,56]$ and $\mathrm{Na}^{+}$coupled glucose transport [22] . JAK2 is further involved in the regulation of $\mathrm{Na}^{+}$coupled neutral amino acid transporter $\mathrm{B}(0) \mathrm{AT}$ (SLC6A19) [23], $\mathrm{Na}^{+}$coupled glutamate transport [24], the $\mathrm{Na}^{+}$and $\mathrm{Cl}^{-}$coupled transport of betaine and GABA [20] and the $\mathrm{Na}^{+} / \mathrm{H}^{+}$exchanger [57]. Accordingly, the kinase is a broad regulator of transport.

In conclusion, the present paper reveals that JAK2 is a powerful regulator of the peptide transporters PEPT1 and PEPT2. The kinase up-regulates the carriers and thus may influence peptide and drug transport in epithelia and tumor cells.

\section{Conflict of Interest}

The authors state that they have no conflicts of interests to disclose. 


\section{Acknowledgements}

The authors acknowledge the meticulous preparation of the manuscript by Lejla Subasic and technical support by Elfriede Faber. This study was supported by the Deutsche Forschungsgemeinschaft and Open Access Publishing Fund of Tuebingen University.

\section{References}

-1 Noon-Song EN, Ahmed CM, Dabelic R, Canton J, Johnson HM: Controlling nuclear JAKs and STATs for specific gene activation by IFNgamma. Biochem Biophys Res Commun 2011;410:648-653.

2 Spivak JL: Narrative review: Thrombocytosis, polycythemia vera, and JAK2 mutations: The phenotypic mimicry of chronic myeloproliferation. Ann Intern Med 2010;152:300-306.

-3 Lopez AF, Hercus TR, Ekert P, Littler DR, Guthridge M, Thomas D, Ramshaw HS, Stomski F, Perugini M, D'Andrea R, Grimbaldeston M, Parker MW: Molecular basis of cytokine receptor activation. IUBMB Life 2010;62:509-518.

-4 Morris DL, Rui L: Recent advances in understanding leptin signaling and leptin resistance. Am J Physiol Endocrinol Metab 2009;297:E1247-E1259.

-5 Yang N, Jiang J, Deng L, Waters MJ, Wang X, Frank SJ: Growth hormone receptor targeting to lipid rafts requires extracellular subdomain 2. Biochem Biophys Res Commun 2010;391:414-418.

6 Brooks AJ, Waters MJ: The growth hormone receptor: mechanism of activation and clinical implications. Nat Rev Endocrinol 2010;6:515-525.

7 Kurdi M, Booz GW: JAK redux: a second look at the regulation and role of JAKs in the heart. Am J Physiol Heart Circ Physiol 2009;297:H1545-H1556.

8 Garnovskaya MN, Mukhin YV, Vlasova TM, Raymond JR: Hypertonicity activates $\mathrm{Na}^{+} / \mathrm{H}^{+}$exchange through Janus kinase 2 and calmodulin. J Biol Chem 2003;278:16908-16915.

-9 Gatsios P, Terstegen L, Schliess F, Haussinger D, Kerr IM, Heinrich PC, Graeve L: Activation of the Janus kinase/ signal transducer and activator of transcription pathway by osmotic shock. J Biol Chem 1998;273:2296222968.

10 Shen XL, Wei W, Xu HL, Zhang MX, Qin XQ, Shi WZ, Jiang ZP, Chen YJ, Chen FP: JAK2V617F/STAT5 signaling pathway promotes cell proliferation through activation of Pituitary Tumor Transforming Gene 1 expression. Biochem Biophys Res Commun 2010;398:707-712.

11 Venkitachalam S, Chueh FY, Yu CL: Nuclear localization of lymphocyte-specific protein tyrosine kinase (Lck) and its role in regulating LIM domain only 2 (Lmo2) gene. Biochem Biophys Res Commun 2012;417:10581062.

12 Yao X, Balamurugan P, Arvey A, Leslie C, Zhang L: Heme controls the regulation of protein tyrosine kinases Jak2 and Src. Biochem Biophys Res Commun 2010;403:30-35.

-13 Mahfouz RA, Hoteit R, Salem Z, Bazarbachi A, Mugharbel A, Farhat F, Ziyadeh A, Ibrahim A, Taher A: JAK2 V617F Gene Mutation in the Laboratory Work-Up of Myeloproliferative Disorders: Experience of a Major Referral Center in Lebanon. Genet Test Mol Biomarkers 2011;15:263-265.

14 Santos FP, Verstovsek S: JAK2 inhibitors: What's the true therapeutic potential? Blood Rev 2011;25:53-63.

15 Pardanani A, Vannucchi AM, Passamonti F, Cervantes F, Barbui T, Tefferi A: JAK inhibitor therapy for myelofibrosis: critical assessment of value and limitations. Leukemia 2011;25:218-225.

16 Baskin R, Majumder A, Sayeski PP: The recent medicinal chemistry development of Jak2 tyrosine kinase small molecule inhibitors. Curr Med Chem 2010;17:4551-4558.

17 Ho K, Valdez F, Garcia R, Tirado CA: JAK2 Translocations in hematological malignancies: Review of the literature. J Assoc Genet Technol 2010;36:107-109.

18 Oh ST, Gotlib J: JAK2 V617F and beyond: role of genetics and aberrant signaling in the pathogenesis of myeloproliferative neoplasms. Expert Rev Hematol 2010;3:323-337.

-19 Tefferi A: Novel mutations and their functional and clinical relevance in myeloproliferative neoplasms: JAK2, MPL, TET2, ASXL1, CBL, IDH and IKZF1. Leukemia 2010;24:1128-1138.

20 Hosseinzadeh Z, Shojaiefard M, Bhavsar SK, Lang F: Up-regulation of the betaine/GABA transporter BGT1 by JAK2. Biochem Biophys Res Commun 2012;420:172-177. 


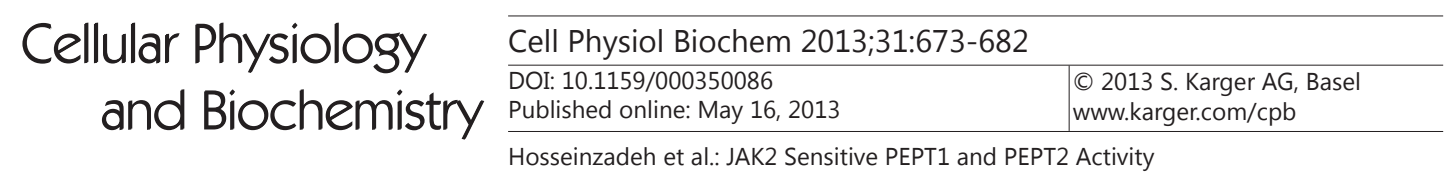

21 Shojaiefard M, Hosseinzadeh Z, Bhavsar SK, Lang F: Downregulation of the creatine transporter SLC6A8 by JAK2. J Membr Biol 2012;245:157-163.

-22 Hosseinzadeh Z, Bhavsar SK, Shojaiefard M, Saxena A, Merches K, Sopjani M, Alesutan I, Lang F: Stimulation of the glucose carrier SGLT1 by JAK2. Biochem Biophys Res Commun 2011;408:208-213.

23 Bhavsar SK, Hosseinzadeh Z, Merches K, Gu S, Broer S, Lang F: Stimulation of the amino acid transporter SLC6A19 by JAK2. Biochem Biophys Res Commun 2011;414:456-461.

-24 Hosseinzadeh Z, Bhavsar SK, Sopjani M, Alesutan I, Saxena A, Dermaku-Sopjani M, Lang F: Regulation of the glutamate transporters by JAK2. Cell Physiol Biochem 2011;28:693-702.

25 Inoue M, Terada T, Okuda M, Inui K: Regulation of human peptide transporter 1 (PEPT1) in gastric cancer cells by anticancer drugs. Cancer Lett 2005;230:72-80.

-26 Rubio-Aliaga I, Daniel H: Peptide transporters and their roles in physiological processes and drug disposition. Xenobiotica 2008;38:1022-1042.

27 Ingersoll SA, Ayyadurai S, Charania MA, Laroui H, Yan Y, Merlin D: The role and pathophysiological relevance of membrane transporter PepT1 in intestinal inflammation and inflammatory bowel disease. Am J Physiol Gastrointest Liver Physiol 2012;302:G484-G492.

28 Rexhepaj R, Rotte A, Pasham V, Gu S, Kempe DS, Lang F: PI3 kinase and PDK1 in the regulation of the electrogenic intestinal dipeptide transport. Cell Physiol Biochem 2010;25:715-722.

29 Rexhepaj R, Dermaku-Sopjani M, Gehring EM, Sopjani M, Kempe DS, Foller M, Lang F: Stimulation of electrogenic glucose transport by glycogen synthase kinase 3. Cell Physiol Biochem 2010;26:641-646.

-30 Boehmer C, Palmada M, Klaus F, Jeyaraj S, Lindner R, Laufer J, Daniel H, Lang F: The peptide transporter PEPT2 is targeted by the protein kinase SGK1 and the scaffold protein NHERF2. Cell Physiol Biochem 2008;22:705-714.

-31 Pieri M, Christian HC, Wilkins RJ, Boyd CA, Meredith D: The apical (hPepT1) and basolateral peptide transport systems of Caco-2 cells are regulated by AMP-activated protein kinase. Am J Physiol Gastrointest Liver Physiol 2010;299:G136-G143.

-32 Yarandi SS, Hebbar G, Sauer CG, Cole CR, Ziegler TR: Diverse roles of leptin in the gastrointestinal tract: modulation of motility, absorption, growth, and inflammation. Nutrition 2011;27:269-275.

-33 Alteheld B, Evans ME, Gu LH, Ganapathy V, Leibach FH, Jones DP, Ziegler TR: Alanylglutamine dipeptide and growth hormone maintain PepT1-mediated transport in oxidatively stressed Caco-2 cells. J Nutr 2005;135:19-26.

-34 Feng J, Witthuhn BA, Matsuda T, Kohlhuber F, Kerr IM, Ihle JN: Activation of Jak2 catalytic activity requires phosphorylation of Y1007 in the kinase activation loop. Mol Cell Biol 1997; 17:2497-2501.

-35 Dermaku-Sopjani M, Sopjani M, Saxena A, Shojaiefard M, Bogatikov E, Alesutan I, Eichenmuller M, Lang F: Downregulation of NaPi-IIa and NaPi-IIb Na-coupled phosphate transporters by coexpression of Klotho. Cell Physiol Biochem 2011;28:251-258.

36 Strutz-Seebohm N, Pusch M, Wolf S, Stoll R, Tapken D, Gerwert K, Attali B, Seebohm G: Structural basis of slow activation gating in the cardiac I Ks channel complex. Cell Physiol Biochem 2011;27:443-452.

-37 Alesutan I, Sopjani M, Dermaku-Sopjani M, Munoz C, Voelkl J, Lang F: Upregulation of Na-coupled glucose transporter SGLT1 by Tau tubulin kinase 2. Cell Physiol Biochem 2012;30:458-465.

-38 Henrion U, Zumhagen S, Steinke K, Strutz-Seebohm N, Stallmeyer B, Lang F, Schulze-Bahr E, Seebohm G: Overlapping cardiac phenotype associated with a familial mutation in the voltage sensor of the KCNQ1 channel. Cell Physiol Biochem 2012;29:809-818.

-39 Eckey K, Strutz-Seebohm N, Katz G, Fuhrmann G, Henrion U, Pott L, Linke WA, Arad M, Lang F, Seebohm G: Modulation of human ether a gogo related channels by CASQ2 contributes to etiology of catecholaminergic polymorphic ventricular tachycardia (CPVT). Cell Physiol Biochem 2010;26:503-512.

40 Hosseinzadeh Z, Bhavsar SK, Lang F: Downregulation of ClC-2 by JAK2. Cell Physiol Biochem 2012;29:737742.

41 Pathare G, Foller M, Daryadel A, Mutig K, Bogatikov E, Fajol A, Almilaji A, Michael D, Stange G, Voelkl J, Wagner CA, Bachmann S, Lang F: OSR1-Sensitive Renal Tubular Phosphate Reabsorption. Kidney Blood Press Res 2012;36:149-161.

42 Daniel H, Kottra G: The proton oligopeptide cotransporter family SLC15 in physiology and pharmacology. Pflugers Arch 2004;447:610-618.

43 Thwaites DT, Anderson CM: $\mathrm{H}^{+}$-coupled nutrient, micronutrient and drug transporters in the mammalian small intestine. Exp Physiol 2007;92:603-619. 


\section{Cellular Physiology $\quad$ Cell Physiol Biochem 2013;31:673-682 and Biochemistry \\ Hosseinzadeh et al.: JAK2 Sensitive PEPT1 and PEPT2 Activity}

44 Kamal MA, Keep RF, Smith DE: Role and relevance of PEPT2 in drug disposition, dynamics, and toxicity. Drug Metab Pharmacokinet 2008;23:236-242.

45 Anderson CM, Thwaites DT: Hijacking solute carriers for proton-coupled drug transport. Physiology (Bethesda) 2010;25:364-377.

46 Gonzalez DE, Covitz KM, Sadee W, Mrsny RJ: An oligopeptide transporter is expressed at high levels in the pancreatic carcinoma cell lines AsPc-1 and Capan-2. Cancer Res 1998;58:519-525.

47 Meredith D: Review. The mammalian proton-coupled peptide cotransporter PepT1: sitting on the transporter-channel fence? Philos Trans R Soc Lond B Biol Sci 2009;364:203-207.

$\checkmark 48$ Foley DW, Rajamanickam J, Bailey PD, Meredith D: Bioavailability through PepT1: the role of computer modelling in intelligent drug design. Curr Comput Aided Drug Des 2010;6:68-78.

49 Newstead S: Towards a structural understanding of drug and peptide transport within the proton-dependent oligopeptide transporter (POT) family. Biochem Soc Trans 2011;39:1353-1358.

50 Brandsch M: Transport of drugs by proton-coupled peptide transporters: pearls and pitfalls. Expert Opin Drug Metab Toxicol 2009;5:887-905.

51 Nakamura T, Yamamori M, Sakaeda T: Pharmacogenetics of intestinal absorption. Curr Drug Deliv 2008;5:153-169.

52 Mitsuoka K, Kato Y, Miyoshi S, Murakami Y, Hiraiwa M, Kubo Y, Nishimura S, Tsuji A: Inhibition of oligopeptide transporter suppress growth of human pancreatic cancer cells. Eur J Pharm Sci 2010;40:202-208.

53 Tsume Y, Hilfinger JM, Amidon GL: Enhanced cancer cell growth inhibition by dipeptide prodrugs of floxuridine: increased transporter affinity and metabolic stability. Mol Pharm 2008;5:717-727.

54 Tai W, Chen Z, Cheng K: Expression Profile and Functional Activity of Peptide Transporters in Prostate Cancer Cells. Mol Pharm 2013;10:477-487.

-55 Gong TW, Meyer DJ, Liao J, Hodge CL, Campbell GS, Wang X, Billestrup N, Carter-Su C, Schwartz J: Regulation of glucose transport and c-fos and egr-1 expression in cells with mutated or endogenous growth hormone receptors. Endocrinology 1998;139:1863-1871.

56 Yokota I, Hayashi H, Matsuda J, Saijo T, Naito E, Ito M, Ebina Y, Kuroda Y: Effect of growth hormone on the translocation of GLUT4 and its relation to insulin-like and anti-insulin action. Biochim Biophys Acta 1998;1404:451-456.

57 Coaxum SD, Garnovskaya MN, Gooz M, Baldys A, Raymond JR: Epidermal growth factor activates $\mathrm{Na}^{+} / \mathrm{H}^{+}$ exchanger in podocytes through a mechanism that involves Janus kinase and calmodulin. Biochim Biophys Acta 2009;1793:1174-1181. 